\title{
Unraveling Stakeholders' Discourses Regarding Sustainable Development and Biodiversity Conservation in Greece
}

\author{
Evangelia Apostolopoulou ${ }^{1,}{ }^{*}$, Evangelia G. Drakou ${ }^{1,2}$ \\ and John D. Pantis ${ }^{1}$ \\ ${ }^{1}$ Department of Ecology, School of Biology, \\ Aristotle University of Thessaloniki, Thessaloniki, \\ ${ }^{2}$ Current Address: Global Environment Monitoring Unit, Institute for Environment and \\ Sustainability, Joint Research Center, European Commission, Ispra, \\ ${ }^{1}$ Greece \\ ${ }^{2}$ Italy
}

\section{Introduction}

The designation and implementation of adaptive conservation strategies able to respond to changing socio-ecological conditions, requires understanding protected areas as complex, interconnected social-ecological systems able to reconcile human needs with biodiversity conservation (Davidson-Hunt \& Berkes, 2003). This consideration leads to perceiving ecosystems involved in biodiversity conservation and the social, political and economic processes and structures behind their management, as interrelated. Sustainable development has been considered, at least the last two decades, as an integrative concept aiming at combining ecological, economic and social issues. However, the concept of sustainable development has received much criticism, whereas the outcomes of successfully combing economic development, social welfare and ecological sustainability can be characterized as quite mixed.

Focusing on the relationships between conservation and development we should refer to Blaikie \& Jeanrenaud (1997) who describe three distinct intellectual paradigms, which also entail fundamentally different approaches to human welfare and assume different set of relations between civil society, the market and the state: the classic/authoritarian, the neopopulist (people-oriented conservation programs such as integrated conservation and development projects - ICDPs, joint or co-management schemes) and the neo-liberal. Similarly, Salafsky \& Wollenberg (2000) analyze three types of linkages between livelihoods and conservation: no linkage, indirect linkage and direct linkage, whereas Nygren (1998) analyzes four ideological perspectives dominant in the current discourse of sustainable environmentalism in the "Third World": (i) environmentalism for nature, (ii)

* Corresponding/Invited Author 
environmentalism for profit, (iii) alternative environmentalism, and (iv) environmentalism for the people. Finally, Adams et al. (2004) offer a conceptual typology of the relationships between poverty reduction and conservation, which is quite relevant to the discussion regarding sustainable development and biodiversity conservation: (i) poverty and conservation as separate policy realms, (ii) poverty as a critical constraint on conservation, (iii) conservation as a process which should not compromise poverty reduction, and (iv) poverty reduction as depending on living resource conservation.

This chapter presents the different discourses between sustainable development and biodiversity conservation strategies, using as an example that of protected areas while presenting at the same time the actions these discourses are promoting. Given also that the research design was based on a multilevel governance approach, a significant aim of this research is to investigate the perceptions of stakeholders acting at different governance levels regarding development and conservation. Towards this goal and in order to disentangle the multiple myths surrounding conservation and development discourses we try to contextualize the latter in their specific institutional fields as well as to reconceptualize (Nygren, 1998). We furthermore investigate how the perverse understanding of the sustainable development concept could cause scale mismatches between ecological and social systems and thus between natural and social processes (see also Cumming et al., 2006).

The analysis followed in this chapter uses primary data obtained from the authors through qualitative research methods. Following the grounded theory approach (Strauss \& Corbin, 1998), 87 semi-structured interviews were conducted in Greece in order to analyze current policy and governance discourses as well as management strategies on sustainable development and biodiversity conservation.

\section{Literature review: About sustainable development and conservation}

A brief description of the historical development of conservation policy is essential to unravel the links between sustainable development and nature conservation and understand the broader context in which these concepts have emerged. The establishment of protected areas has been the leading conservation strategy since the late $19^{\text {th }}$ century (Adams et al., 2004). The different purposes of the wilderness movement and the wise use movement raised the focus of conservation and utilization - oriented dialogues (Kalamandeen \& Gillson, 2007). These two opposing perceptions of nature have always reflected a wavering between idealistic and mechanistic representations of nature (see also Foster, 2002). The latter has been evident in the history of the establishment of protected areas which has been based on aesthetic, moral (Thiele, 1999), political and economic criteria as well as on the displacement of indigenous people (Abakerli, 2001).

The gradual increase in the number and extent of protected areas during the 20th century led to the establishment of networks of protected areas during the '90s. The Habitats Directive and the establishment of the Natura 2000 Network were influenced by the political and economic context of the period, especially the "meteoric rise of sustainable development'" (Peterson et al., 2005). This has been associated with a shift towards consensus-driven policies based on the belief that longstanding conflicts between 
development and conservation could be resolved through collaborative governance (Apostolopoulou \& Pantis, 2010). Similarly, the ecological modernization theory emerged during the ' 80 s and remains until today dominant in environmental sociology, fact that can become evident by the prevalence of the opinion that environmental protection, including biodiversity conservation, can be a potential source of economic or developmental growth (Clark \& York, 2005), something in line with the core principles of sustainable development. On the other hand, the role of the market as a tool against biodiversity loss has been linked to private property rights over natural resources (Mukhopadhyay, 2005), an expanded role for non state economic and development actors, and results-based regulatory approaches, typical characteristics of neoliberal governance (McCarthy, 2006).

In current discourses the terms of sustainable development, ecological modernization and collaborative governance constitute the core ideas around which the dominant conservation policy is being framed. The new approach to sustainable development and management of protected areas which became institutionalized in the European policy of protecting the natural environment with the Habitats Directive (92/43/EEC) reflects this broader understanding of the relationship between society and nature. To understand what is involved in this perception it is crucial to consider the context in which it was formed (see also Apostolopoulou, 2010).

The sustainable development concept first appeared in the early '70s. At that time, the capital accumulation crisis combined with a major ecological crisis, lead to the emergence of the ecological issue as an independent and important face of social and political struggle. Amid the increasing intensification of environmental problems and the increasing inability of the environmental policy to solve them (Weale, 1992) and sufficiently respond to radical ecological movements (Hajer, 1995), the issue of environmental protection has officially -i.e. institutionally- emerged. The emergence of measures for the protection of the natural environment by state policies as a separate issue came after a relatively long period during which EU's environmental policy had not set specific rules for protecting the natural environment. On the other hand, EU's policies included from the beginning a variety of social, economic and technological objectives the achievement of which would further enhance growth. Specifically, the treaty on European unification in 1957 did not contain elements of environmental policy and the First Action Programme for the Environment was launched in 1972 (Naxakis, 1997). Furthermore, the sustainable development concept also served as a reaction to the growing literature which addressed the need to set limits on development and has been initially set with the publication of the Club of Rome in 1972.

The overall ideology of that era, and particularly the fact that the end of the three postwar decades of dynamic economic growth has been followed by the entry into a period of crisis and recession, played a major role in the autonomous emergence of ecological issues. The official entry into the global scenery of the concept of sustainable development has been followed by the emergence of the concept of participation of "civil society" in environmental governance initiated by the United Nations and especially through the Brundtland report (World Commission on Environment and Development [WCED], 1987). The Brundtland report was practically the formal adoption of a system of ideas, which was substantially based on the concept of "ecological modernization" (see also Hajer, 1995; Weale, 1992). 
Without ignoring the fact that sustainable development and ecological modernization do not have the exact same meaning and interpretation, nevertheless it is considered that they largely overlap and coincide (see Blowers, 1998; Dryzek, 1997; Jänicke, 1997). The theory of ecological modernization has its roots in the work of the German sociologists Joseph Huber and Martin Jänicke (Spaargaren, 1997) and began to emerge more clearly in Western countries and international organizations in the early ' $80 \mathrm{~s}$. In particular, by the mid-80s it has been widely recognized as a promising alternative policy while following the general acceptance of Agenda 21 in 1992 it began to be the dominant approach to environmental policy (Hajer, 1996).

Sustainable development is often defined as the development that meets present needs without jeopardizing the ability of future generations to meet their own needs (according to the Brundtland report, see WCED, 1987). However, most neoclassical economists understand sustainable development as the development in which consumption remains undiminished by time (Vlachou, 2005). Specifically, they suggest that the concept of sustainability should focus on maintaining the productive opportunities of future generations, without specifying if it is determined by physical capital or natural boundaries (Vlachou, 2005). Similarly, the theory of ecological modernization seeks to broadly analyze the way in which today's societies organize their economic, political and cultural institutions to cope with environmental crises. Based on this logic, ecologically modernized societies are those that incorporate environmental principles into the design of institutions to regulate human interactions with nature. The concept of democracy and constitutionally guaranteed rights and freedoms are the necessary institutions for ecological modernization in the sense that they operate as self-regulating mechanisms that have the potential to alleviate the human impacts on the planet. Alongside the market, further industrialization and technology are considered to be the main forces of modernization that will lead to ecological sustainability (Hajer, 1995; Mol, 1995, 2002; Mol \& Sonnenfield, 2000; Mol \& Spaargaren, 2000; Spaargaren, 1997, 2000).

If the concept of sustainable development has lost some of its original "glory" the same does not apply to the ecological modernization theory, which is a prominent neo-liberal theory and one of the leading theories in environmental sociology (York \& Rosa, 2003). Its widespread prevalence in shaping the current environmental policy is evident in the dominant approach that environmental protection should not be treated as an obstacle to economic development, but rather as a potential source for future growth (Weale, 1992, p. 75), a view highly related to the concept of sustainable development. This perception is accompanied by the assumption that the "ecological rationality" will emerge from already existing institutions rather than from radical environmental movements. As Clark \& York (2005) argue the theory of ecological modernization is basically a functionalist theory, in the sense that it does not see the emergence of ecological rationality as derived primarily from social conflicts but rather from ecological enlightenment within the key institutions of modern society (Mol, 1995). As a response to the increasing criticism regarding the intensification of environmental problems in the existing socio-economic system and delays in the emergence of this "rationality", supporters of the theory consider it to become a prevalent trend in the near future.

In particular, they argue that in the early years of modernization states degraded the environment, while in its last stages environmental concerns will diffuse through society, 
leading to the restructuring of major political, economic and social institutions towards ecological sustainability and social welfare (Mol, 1995). It is important to note that discussions of these concepts are mainly oriented to performance issues (efficiency), a focus that is not at all accidental. The criterion of efficiency is fully accredited by various public and private economic actors and establishes a common ground within the theory of ecological modernization that manages to combine the concerns of environmentalists, businesses and states. It is typical that many environmental organizations have embraced this consensual framework for discussion because it promises to make environmental protection "attractive" to governments and businesses whose cooperation is needed for environmental organizations to achieve specific reformist objectives (Hajer, 1995). The collaborative governance concept is also based in the same core ideas by supporting the participation of a variety of stakeholders in a context of apparent equity and fairness.

In general, strategies promoting sustainable development and ecological modernization goals in the context of collaborative governance do not address environmental degradation as an inherent characteristic of the current socio-economic system. Moreover, these perceptions often get to support that the forces of modernization will lead to the dematerialization of society and will succeed to decouple the economy from energy and material consumption, thus allowing the human society to overcome the environmental crisis within the present socio-economic system (Mol, 1995; Spaargaren, 1997). Nevertheless, so far, and despite the numerous signed conventions and directives, the various policy objectives and legislative measures towards the conservation and protection of the natural environment and biodiversity, the protection of human health, the rational use of natural resources etc., economic development remains the primary objective at both international and EU levels, thus weakening the effectiveness of existent environmental measures (Naxakis, 1997). After all, as Brand and Görg (2003) argue, politics on the conservation of biodiversity focus more on the creation of a stable political institutional framework for its commercialization, rather than on its actual conservation.

The above insights are essential in order to disentangle the variety of approaches regarding sustainable development and biodiversity conservation. Even though debates around the issues described above may not be transferred as such in the case of biodiversity conservation and protected areas they are relevant in order to contextualize the latter. Moreover, it is now obvious that debates regarding the relationship between biodiversity conservation and sustainable development are closely related to different approaches regarding the relationship between society and nature. These debates are of fundamental importance for the designation and implementation of management strategies and more generally for the direction and content of future conservation policy and governance.

\section{Methodological approach}

In our research we adopted a grounded theory approach. Grounded theory has been widely used in environmental research (e.g. Berghoefer et al., 2010; Kittinger et al., 2011) and produces theories that are likely to offer insight, enhance understanding and provide a meaningful guide towards action (Strauss \& Corbin, 1998).

During the process of grounded theory building, four analytic and not strictly sequential phases were identified: research design, data collection, data analysis and literature 
comparison. In the initial phase (sampling) of the research, when the major purpose was to generate as many categories as possible, we gathered data using the method of snowball sampling, asking our initial list of individuals who they thought would be good informants based on their experience and then tried to gather data in a wide range of pertinent areas. We also followed the method of purposive sampling that allowed us the use of personal judgment for the selection of the respondents who had the knowledge and the experience to cover the topics of the research. Once the initial categories were formed, then the sampling became more specific. The sample was then selected according to the "theoretical sampling" method, based on analytic questions and comparisons, pinpointing places, people or events to maximize the chances of discovering variations among concepts (Corbin \& Strauss, 1990). This meant that the sample definition and requirements evolved during the research process itself. The criterion for stopping the research of a certain category was based on the category's "theoretical saturation", a major component of our research methodology since without this the theory would be unevenly developed and lacking density and precision (Strauss \& Corbin, 1998).

Overall, we conducted 87 face-to-face semi-structured interviews with actors acting at several governance levels between January of 2007 and September of 2008 (see Table 1). Research questions were open, exploring issues regarding the relationships between sustainable development and biodiversity conservation with specific reference to the role of local community, the state and the market. The interviews were then transcribed and the transcribed passages were labeled with codes. In grounded theory data analysis is a welldefined process that begins with basic description and moves to conceptual ordering and then on to theorizing (Patton, 2002). Thus, the main analytical techniques include three types of coding: open, axial and selective coding (for further details see also Apostolopoulou \& Pantis 2009, 2010). The main purpose of coding is the same as in other types of qualitative research (Padgett, 1998; Patton, 2002) but its level of specificity is what distinguishes grounded theory from other qualitative methods.

Interviewees were also asked to give specific examples in line with our approach to disentangle confusing and contradicting discourses and investigate what actions they actually support in practice. We selected as case studies Zakynthos Marine National Park and Schinias National Park as in both cases previous research has already been conducted by the authors, thus a relatively good knowledge on the actual situation served as a basis for the interpretation of research outcomes. Moreover, both cases are exceptional examples, since the history of their establishment as national parks has been characterized by significant conflicts between development and conservation.

We should clarify that the formulation of the research questions was based on an extensive literature review and on the described theoretical section (see section 2), in order to ensure that they will serve to investigate the relationship between sustainable development and biodiversity conservation. Similarly, given that the objective of this research is to use empirical research as a start for a broader discussion, the findings of the analysis are linked to relevant existing scientific literature and in particular to research on human-environment relationships. This is in line with the focus of coding in grounded theory which is not based only on the opinion of the individual interviewees but also on the core emerging concepts which can guide researchers from "description to conceptualization and from the more specific to the general or abstract" (Strauss \& Corbin, 1998). 


\begin{tabular}{|c|c|}
\hline Stakeholders participating in Greek biodiversity governance & $\begin{array}{l}\text { Number of } \\
\text { interviews }\end{array}$ \\
\hline \multicolumn{2}{|l|}{ Central administration } \\
\hline Ministry of the Environment & 14 \\
\hline Ministry of Rural Development and Food & 5 \\
\hline Ministry of Development & 3 \\
\hline Ministry of Economics & 1 \\
\hline Ministry of Tourism & 1 \\
\hline National Center for the Environment and Sustainable Development & 1 \\
\hline Council of the State & 1 \\
\hline Total & 26 \\
\hline \multicolumn{2}{|l|}{ NGOs } \\
\hline World Wide Fund for Nature Greece & 5 \\
\hline The Sea Turtle Protection Society of Greece & 3 \\
\hline Hellenic Ornithological Society & 2 \\
\hline Hellenic Society for the Study and Protection of the Mediterranean monk seal & 2 \\
\hline Mediterranean association to save the sea turtles & 1 \\
\hline Hellenic Society for the Protection of Nature & 1 \\
\hline Pan - Hellenic Network of Ecological Organizations & 1 \\
\hline $\begin{array}{l}\text { Hellenic Society for the Protection of the Environment and the Cultural } \\
\text { Heritage }\end{array}$ & 1 \\
\hline Total & 16 \\
\hline \multicolumn{2}{|l|}{ Management agencies and local administration } \\
\hline Management agency of National Park of Schinias - Marathon & 9 \\
\hline Management agency of National Marine Park of Zakynthos & 5 \\
\hline Municipalities and Regions & 5 \\
\hline Central Union of Municipalities and Communities of Greece & 1 \\
\hline Total & 20 \\
\hline \multicolumn{2}{|l|}{ Other key stakeholders } \\
\hline $\begin{array}{l}\text { Companies providing consulting and assessment services in the field of } \\
\text { nature conservation }\end{array}$ & 3 \\
\hline Greek Biotope/Wetland Center & 2 \\
\hline Greek General Confederation of Labor & 2 \\
\hline $\begin{array}{l}\text { The centre of Athens labor unions - Department of environment and } \\
\text { international relations }\end{array}$ & 1 \\
\hline Hellenic Federation of Enterprises & 1 \\
\hline Pan - Hellenic Federation of Tourism Enterprises & 1 \\
\hline Technical Chamber of Greece & 1 \\
\hline The Mediterranean Initiative of the Ramsar Convention on Wetlands & 1 \\
\hline Total & 12 \\
\hline \multicolumn{2}{|l|}{ Scientific community } \\
\hline Aristotle University of Thessaloniki & 4 \\
\hline National \& Kapodistrian University of Athens & 4 \\
\hline Scientific institutions & 2 \\
\hline National Centre for Social Research & 3 \\
\hline Total & 13 \\
\hline TOTAL & 87 \\
\hline
\end{tabular}

Table 1. The sample of interviewees. 
During data analysis we chose to categorize discourses (see Phillips \& Jorgensen, 2006) and not categories of stakeholders as such, a choice based both on theoretical arguments as well as on empirical findings. Regarding the theoretical arguments, following Blaikie \& Jeanrenaud (1997, p. 47) we argue that different actors tend to use different parts of specific paradigms and approaches in eclectic and contradictory ways in order to support their projects, policies and often their special interests. Therefore, a focus on ideas and paradigms is valuable in order to disentangle dominant policies and practices. As far as empirical findings are concerned, the analysis of our qualitative empirical data confirmed that the majority of stakeholders tend to combine different arguments and conceptualizations of the linkages between conservation and development in order to support different claims. Even if specific stakeholder groups, such as state officials, adopted a more specific standpoint reflecting a specific ideology or even if in some cases one approach was more dominant, e.g. in the case of private economic actors, in many occasions stakeholders were using different arguments in order to support these approaches.

Therefore, the process of data analysis resulted in the construction of a conceptual model according to which the variety of stakeholders' discourses relating sustainable development to biodiversity conservation is categorized in the three main approaches that are described in the results and discussion section, as well as in several subcategories regarding the role of local community (including the role of NGOs), the role of protected areas, the role of the market and the state as well as the explanation of (natural resource) conflicts between development and conservation with reference to the two case studies.

\section{Results \& discussion}

\subsection{Biodiversity conservation and sustainable development as incompatible discourses}

This approach could be divided in two different but interlinked discourses, in the sense that they result to the same conceptualization of the relationship between nature and society: in the first one the priority lies explicitly on biodiversity protection and in the second one on development. Each discourse, even if it often has completely different foundations and arguments, by putting either development or protection as a priority, leads to the reproduction of a dichotomy between nature and society.

\subsubsection{Development as a barrier to conservation}

One of the two dimensions of this approach, the conceptualization of development as a barrier to conservation, was dominant mainly between stakeholders from NGOs and Universities. Underneath this approach lies a strong moral imperative regarding nature's intrinsic value as well as a strong belief that development should be understood as the main cause of current biodiversity loss. The latter was grounded in the chronic failure of Greek state conservation policy to ensure the conservation of biodiversity which was mainly attributed to the explicit prioritization of development and public works. Sustainable development was interpreted as mainly based on rhetorical arguments in order to support actions and initiatives that are not actually "sustainable", more or less as a term used in official reports or policy documents without being based on concrete actions that take seriously into account biodiversity conservation concerns. 
Interviewees adopting the above arguments often failed to distinguish between corporate developmental interests and local community livelihoods and thus to explain the roots behind the current direction of Greek economic development. Conflating sustainable and non-sustainable human activities has in its core the idea that humans are an a priori threat to biodiversity conservation leading to calls for strict nature protection excluding any type of human activities including those of the local community.

The above approach is quite similar to what has been characterized as the classic or authoritarian paradigm to biodiversity conservation (Blaikie \& Jeanrenaud, 1997) and one significant element of this discourse was the explicit support for the establishment of more protected areas as the dominant proposed strategy for biodiversity conservation. The effect of the presence of local communities and in particular of indigenous people around protected areas (Chatty \& Colchester, 2002), along with the economic and social impacts of these areas have been widely acknowledged and investigated (Adams \& Hulme, 2001; Igoe, 2006; McNeely, 1993), mainly highlighting the tendency of conservation policy to act against the economically weaker groups of local communities. The establishment of protected areas has often been accompanied by the financial exploitation of these areas and the degradation of local communities. One of the most significant consequences is related to the displacement of local populations with direct impacts on their survival, as well as on livelihood provision (Brown, 1998; Cernea, 1997; Cernea and Schmidt-Soltau, 2006; Chatty \& Colchester, 2002; Geoghegan \& Renard, 2002; Gjertsen, 2005; Harper, 2002; Knudsen, 1999; Nygren, 2005). Even if the majority of the research on the unequal costs and benefits of conservation policies and on their increasing economic and social consequences have focused on "developing" countries (e.g. Sodhi et al., 2010; Swetnam et al., 2011) the last decades research on "developed" countries is also increasing (Apostolopoulou \& Pantis, 2010; Foster, 2002; Haggerty, 2007).

However, interviewees who considered development as a barrier to conservation tended to underestimate the social dimensions of conservation policies. The latter was linked to the general tendency towards blaming humanity or mankind as a whole for environmental degradation. Moreover, usually interviewees mainly blamed the economic "weaker" social groups following the dominant ideology that poverty and environmental degradation are interlinked, considering poverty as a cause of environmental degradation and not both as a result of the existing socio-economic structures. Interviewees often considered that local communities by prioritizing their individual welfare could easily adopt short-term developmental goals and initiatives without taking into account environmental concerns. The conceptualization of local community as a group of people caring only for short-term profit from rapid development has been often associated with a more general understanding of society as a unified entity without significant differentiations (e.g. economic, social, political, gender), but as divided between two poles: the people that are environmental conscious and those that are not. It is worthy to note that many interviewees considered the latter category as a typical example of Greek local communities, attributing major responsibilities for biodiversity loss to local people, thus arguing that non-conservation is not only a state choice but also a social demand. Interestingly, this claim was in accordance with arguments of private economic actors and state officials who considered conservation as a barrier to development (see §4.1.2. and also Apostolopoulou \& Pantis, 2010).

The way that the above argumentation has been used in order to explain the conflicts between development and conservation that have emerged in the two case studies, the National Park of Schinias and the National Marine Park of Zakynthos, is remarkable. The following quote from 
a non-governmental organization (NGO) representative regarding the conflicts between development and conservation in National Marine Park of Zakynthos is indicative:

"The best way to end these unresolved conflicts between biodiversity and development is to buy the beaches that are the matter of debate. This has already happened -from an NGO-for one beach with very positive results. Sustainability is not an issue any more in these areas; they have abandoned it forever when they uncritically adopted mass tourism. Local people create problems each summer and they will continue to do the same because they understand the protected area as a barrier to their welfare so the only realistic way to proceed and ensure biodiversity conservation is unfortunately without them..."

The conceptualization of local community through the adoption of the term "civil society" proved in many cases as a crucial factor leading to the homogeneity of local people's interests. The determinative role of "civil society" in environmental policy has firstly emerged during the international meeting in Rio (1992) and today the term is more or less established. Civil society includes all the organizations and institutions which, at least theoretically, are located outside direct state control like associations, community groups, corporations, NGOs as well as business interests (Scholte, 2004). Prominent role in environmental and conservation policy is given to NGOs at international, national and local levels. It is characteristic that many interviewees consider that NGOs' participation is equal to public participation stemming from the belief that NGOs are the main representatives of common opinion. It is crucial to notice that the establishment of NGOs has been increased approximately $400 \%$ the last twenty years. These organizations are quite heterogeneous not only regarding the scale of their activity (local, national, international) but also in the forms of their organization, their goals, as well as their general standpoint towards political processes (De Angelis, 2003). However, in many cases they share common economic goals with business cycles while in other cases they purposefully promote the values and policies of neoliberal state and market (De Angelis, 2003).

A crucial point of this research is that representatives of NGOs tended to consider themselves during interviews as representatives of society without clarifying if they represent the interests of a specific part of society, whilst in many cases the only role that they were acknowledging for local people was the need to include them in environmental education activities. This seems to be a general trend especially if we take into account the fact that none of the international organizations which are promoting the establishment of protected areas has adopted and published explicit policies and official principles which would forbid the displacement of local people from these areas (Cernea \& Schmidt-Soltau, 2006). However, big international organizations which are active in biodiversity conservation and which are lobbying for more protected areas, mainly at international and national levels, are receiving significant economic support from states, public and business whereas small-scale and mainly local NGOs working along with local communities in order to actively support the combination of sustainable development and biodiversity conservation are mainly based on the voluntary work of activists (Chapin, 2004).

Another issue raised here is that as in the past the movement of strict nature protection found common ground with the utilitarian movement in the creation of national parks, nowadays this seems to happen again. In particular, the fact that the idea that environmental and conservation initiatives and goals come first has often been used as an excuse for excluding local people and promoting private economic interests revealing that 
often in this classic approach the problem is not people in general, but local people and especially indigenous people. It is indicative that many interviewees were highly critical towards local practices but at the same time they were supportive of private market-based initiatives for conservation. Not only powerful economic interests are not distinguished as potentially harmful for biodiversity, but to add to that, local people are blamed for unsustainable behavior with the common arguments that they are either not educated or due to their small-scale and short-term economic interests they do not take seriously into consideration environmental impacts. Thus we could argue that this approach is partly an inverted image of the "human-in-nature" approach that reproduces the division between human society and environment leading to serious mismatches between social and ecological systems.

\subsubsection{Conservation as a barrier to development}

This discourse was dominant in a small group of state officials and private economic actors and has been largely based on the criticism regarding unsatisfactory current developmental trends in Greece. Interviewees adopting this view argued that current environmental laws are very strict hindering opportunities for real development in Greek rural, marine and coastal areas. Particular emphasis was put on Natura 2000 network and the large percentage of Greek land $(27,13 \%$ of national terrestrial area) that it covers. Many interviewees were adopting a mix of different arguments in order to support this approach whereas local community has mainly been portrayed as poor people-victims of strict biodiversity policies. However, the real focus of this approach was related to concerns regarding the fact that corporate interests do not select Greece for their investments because of the dominance of strict conservation measures. The following quotes from a private economic actor are quite indicative:

"Natura 2000 network has been designed without taking into account the developmental opportunities that existed in these areas which are now "trapped" inside the boundaries of the network. The result is that more than the $50 \%$ of areas ideal for tourist, residential and energy development are now Natura 2000 sites. Inside these areas, but also outside them because of the strict legislation, an investor should wait four years or more in order to receive a "yes" or a "no" from the Greek state regarding the authorization of his project. Thus, in this era of competition you should wait at least four years for investment in Greece! You can understand that this is detrimental for any kind of development and completely contrary to sustainable development: sustainability is supposed to be taking into account economy-society-environment; If it considered only the last two things then it wouldn't be called development".

And:

"Sustainable means "viable" and this clarifies current extremities in the interpretation of the term in Greek discourses considering that sustainable is equal to "inheriting" resources to the next generations. But who can guaranty to us that the future societies of our children or grandchildren will have the same needs with us? Technology continuously invents and develops new materials and substitutes for the rare ones".

It is rather remarkable that interviewees adopting this discourse had a completely different opinion regarding biodiversity policy in Greece. In contrast with all other interviewees (see also Apostolopoulou \& Pantis, 2009), they argued that there is a national biodiversity strategy and a clear priority from Greek state to promote and support the establishment of protected areas and especially Natura 2000 network. 
It is important to keep in mind at this point the huge struggle regarding the issue of arbitrary building, which has emerged during the voting of the new national (Greek) biodiversity law in 2011. Even though this happened after the period that this research was carried out, it has been quite indicative of the predominance of this minority discourse during interviews in real biodiversity politics in Greece.

Simultaneously, the local community has been portrayed in quite contradicting ways. The statement of K. Brown (2002) that "development perspectives have often argued that conservation is a threat to human welfare and highlight the exclusion of local people from protected areas as a denial or rights to resources and as undermining livelihoods" was dominant in this discourse, which on the other hand was combined with the conceptualization of local people as environmentally uneducated. The "value" of local people seemed to be considered as increased because of their role as voters at least for the ministries' and local administration's political leadership. As a ministry representative stated:

"Sustainable development is good in theory. But can it be really implemented in practice? Big interests will always prioritize development. [...] EU is trying to reach consensus between environment and society and is willing to take into account citizens' opinions. They were imagining sensitive citizens though, but in reality citizens use environmental protection as a "flag" while claiming other things. Therefore, state leadership will conflict only for something of huge importance. And since people are those voting for the existing governments we should prioritize people's preferences -which are clearly development and profit-, especially in a small underdeveloped country like Greece".

This has been more clearly illustrated in stakeholders' opinions about the conflicts in the two case studies. The following quote is indicative:

"The participation of local community in combining sustainable development and biodiversity conservation is risky. People who have interests will try to promote their interests and just name this "sustainable development" and in this way personal interest for profit will dominate, exactly as it happened in the cases of Schinias and Zakynthos. But on the other hand these people are those who really know these areas, own land there, thus you cannot exclude them from decision-making or decide the transformation of these areas to protected parks, which stands for actually taking over their land based on some international agreements or NGOs strategies".

However, the fact that the above argument if expressed in a different way can be used for exactly the different purpose from populist discourses or from the "human-in-nature" approach on biodiversity conservation should sensitize researchers to focus both on the social construction of nature and on the politics of conservation and development including the actual practices that each discourse supports.

\subsection{Biodiversity conservation and sustainable development as compatible discourses: Green economy, ecosystem services and "win-win" scenarios}

A different stakeholders' discourse, the dominant one in comparison with all others analyzed in this chapter, consisted of the main idea that biodiversity conservation and sustainable development could and should be combined with the main goal to support development through biodiversity conservation. Interviewees adopting this approach, tended to emphasize that environment is a common good, from the conservation of which every individual member of society could significantly benefit. In this context, ideas of 
collaborative and multilevel governance were dominant in the discussions. Even though the term civil society was the main term used for the local community also in this discourse, in contrast with the previous cases, this time local community was portrayed as consisting of more or less equal groups of actors between which "win-win" solutions could be reached. Behind this approach lies the ideology that social groups with different interests could codecide and reach consensus through negotiations. A central argument supporting this potential has been based in the importance to render biodiversity protection politically viable through the development of new partnerships between various actors in the context of the common expectation for economic development, something in line with ecological modernization theory (Fisher \& Freudenburg, 2001).

The idea of green economy is placed at the core of this discourse as well as the attempt to explicitly link economy to biodiversity conservation. The core issue here proved to be not the conservation of biodiversity as such but as a potential strategy that would benefit economic development. This was a dominant discourse among interviewees from different organizations and sectors, even though there was a continuum of approaches, from the more explicitly economic to the more socially conscious. In particular, interviewees located in the first end of this continuum, explicitly referred to the necessity to include nature into market through its valuation. This general proposal was further supported by more specific ones in the context of the popular motto, "the polluter pays" or even "the user pays". In the first case, it was argued that environmental degradation, including biodiversity loss, has been primarily caused by polluting activities, infrastructure or overexploitation of natural resources and thus should be arranged through negotiations among relevant actors and compensations should be made mainly from the responsible enterprises. In the second case, it was argued that each person visiting a national park or swimming in a protected beach should pay for using this natural "service". This is in line with what Naxakis (1997) explains as the dominant response to environmental problems: "to give prices to nature, to consider that natural resources have value, they are commodities, since the prices are those regulating the changes of available quantities of goods. The economic valuation of natural resources -from the air that we breath, the oceans, the forests, the fauna and flora- and their exchange in the market will determine according to neoliberals their demand and consumption rates, will thus regulate their exhaustion (destruction) rate".

In particular, interviewees from central and local administration, NGOs as well as private economic actors argued that the transition to a green economy, including a green tourist industry, green investments and banking, as well as green products, by regulating supply and demand will lead to the increase of the price of products and services which are rare, including ecosystem services, endangered species, habitats and landscapes and will accelerate their protection or in some cases even their replacement through technological innovation. This approach by adopting the core arguments of the ecological modernization theory is in line with the main arguments of the classical theories of ecological economics. In particular, the latter theories support that increased demand for environmental quality, expressed mainly through the preference for green commodities and services, would force governments and business to invest in ecologically friendly technologies and practices. Financial support for these technologies would in turn be possible because of the increased profit that these would bring. However, interviewees tended to underevaluate the fact that if value and scarcity are inversely related then species recovery and relative abundance could paradoxically result in reduced support for conservation (Vira \& Adams, 2009). 
Simultaneously, interviewees tended to support that the causes of biodiversity extinction are strongly related to the communal property of natural resources. As an interviewee noted:

"If a rare species belongs to everybody then it belongs to no one and therefore nobody has the responsibility for its conservation and management. To put it simply: nobody cares if it disappears because it won't cost anything to him".

This has been strongly attributed to the incapacity of Greek state to effectively conserve valuable ecosystems and combine in practice sustainable development with biodiversity conservation. The absence of explicitly defined property rights has been considered as a main factor, which helps and legitimates state intervention while at the same time does not allow the market to take an active role in managing conservation problems. These arguments have been further supported through the open support for free businesses and in general for a free market unobstructed from both governments and employees (see also Jamal et al., 2003). The market was portrayed here as rational, fair and representative of social interests whereas according to more extreme opinions it was considered as able to ensure the democratic distribution of ecosystem services and natural resources.

Following the above line of argumentation, interviewees explained that they consider as necessary the further privatization and commercialization of natural resources, while arguing that private property rights in individual parts of natural environment could partly deal with many current threats to biodiversity. As Fraser (1996) explains, a neoliberal approach aligns government and capital more directly, thus leading to a variety of services and goods which are neither public nor commodities, but more or less hybrids combining characteristics of both forms. This was expressed during interviews while discussing the role of protected areas on conservation and development where it was argued that initiatives towards the commercialization of landscapes and environmental "experience" could be good solutions in order to make protected areas economically viable and a core element of tourist and residential development. This is actually a very popular trend, which has led to many partnerships between parks administration, especially national parks, and mainly tourist industry in the face of constantly decreasing state funding for nature conservation (Searle, 2000). The following quotes from a representative of the tourist industry and a member of local administration regarding the two national parks are indicative:

"Eco-development and thus ecotourism set as the main economic touristic value, the preservation of innocence, wilderness and of the broad variety of nature that is essential for the modern societies that are trapped in the large cities, the fast working conditions, even in the large luxurious apartments of the big cities. Volunteering, extreme sport activities and generally the "mother nature" package that is considered as a shelter from the wild city life, is rapidly evolving as the new way of commercializing sustainability, thus enhancing the huge benefits one can gain from the nonmonetary economic development. This model if adopted in Schinias and especially in Zakynthos would transform these areas into green and expensive paradises".

And:

"Many experts agree that nature which is pristine can remain like this only if it brings money. Local people in Zakynthos, and generally in Greek rural areas, are still trying to gain money from the exploitation of natural resources but they could achieve the same, if not more, by guiding tourists into their beautiful and valuable areas. Without tourists and their money neither local economies nor endangered species have the prospect to survive". 
The dominance of these approaches has also been evident in the fact that the last 30 years the valuation of ecosystem services has been proved to be one of the faster developing research areas in environmental economics (Jenkins et al., 2010; Jim \& Chen, 2009; Lange \& Jiddawi, 2009). This has been a core argument of many interviewees, especially those more familiarized with environmental research, and it was widely used in order to support that these ideas have somehow "naturally" evolved in the era of modernity and have now become a highly respected scientific endeavor. Reference to ecosystem services, mostly seen as economic benefits provided by natural ecosystems, was not only a dominant theme during interviews but it can also be considered as the dominant trend in conservation science (MA, 2003; McCauley, 2006). However, research focusing on these issues tends to support approaches which are based in consumers' preferences and which are compatible with the usual monetary system of valuating competitive products and services (e.g. Jenkins et al., 2010).

Supporters of these approaches defending themselves towards criticism for attempts to costing and selling natural environment, argue that the main goal it is not to select a specific price ( $\$$ price tag») for natural environment or its components, but to express in economic terms the result of a change in the benefits of ecosystem services in relation to other services that people are willing to pay for (e.g. Jenkins et al., 2010), thus to calculate the potential, as well as the amount, that "consumers" are willing to pay for conserving natural environment in comparison to other "products" (Hanley \& Shogren, 2002; Randall, 2002). As Vira \& Adams (2009) argue "the ecosystem services approach may provide a useful additional argument for conservation, but practitioners should be cautious about the potential pitfalls of utilizing economic metaphors that are not always perfectly related to the biological systems that are the subject of conservation interest". They furthermore explain that "while natural capital is a useful economic concept, it does not capture the full complexity of relations between genes, species, and ecosystems that is associated with the term biodiversity (cited Wilson, 1992)". This is of particular importance for conservationists, who seem to adopt ecosystem services as the new "win-win" strategy, which in contrast to sustainable development puts the emphasis of this dual relationship on conservation and not on development. On the other hand, the concept of ecosystem services is essentially based on human valuation systems, which are based on changing consumer preferences, willingness to pay, and technological advances (Vira \& Adams, 2009). As Tallis et al. (2008) explain "if policy and financial incentives for conservation of ecosystem services are to be successful and equitable, we will also need a solid scientific understanding of how services flow from one region to another, what human groups benefit from ecosystem services, and what groups or populations would need to be compensated for protecting those services". Moreover, there is "a strategic risk in justifying biodiversity conservation primarily in terms of ecosystem services", as McCauley (2006) points out. One should thus be aware of the potential risk that economic benefits from services that are valued by human society will overwrite and outweigh noneconomic justifications for conservation (Redford \& Adams, 2009).

In the above context, proposals for economic benefits from the establishment of protected areas dominated interviews. The most dominant one concerned proposals for investigating visitors' willingness to pay for visiting a protected area or for establishing a small market based on souvenirs sold in the protected areas. Simultaneously, proposals for partnerships with the tourist industry proved to be quite popular. The conceptualization of public access 
to recreation as a commodity has been a constantly emerging topic in scientific literature and since the early '90s the optimal way to "charge" people for recreational purposes has been considered to be a market under constant development (see Bishop \& Phillips, 1993). As Kiss (2004) notices "ecotourism represents one facet of the sustainable use approach, in which biodiversity is regarded as a product to be sold to consumers (using the terms broadly)". As a representative of an NGO put it:

"There have been many thoughts about promoting ecotourism and partnerships with the private sector, but in Zakynthos - as well as in Schinias and in Greece in general- we are too far from these approaches - the problem is not the protected area but the investment projects. We do not have the necessary development law, which would help each local landowner or business owner to think in an environmentally friendly way and start acting towards this direction [...] It is a matter of time that these people realize that environment and biodiversity conservation can give major job opportunities and bring money to their areas. Similarly, it is a matter of time for administration to realize that valuation of ecosystem services is crucial for the survival of Greek protected areas".

The latter proposals were often related, in economic actors' discourses, to proposals for promoting the importance of protected areas for residential development. This is in line with peer-reviewed publications (Pejchar et al., 2007), where authors argue that the most direct benefit from such initiatives would be the decrease in the total amount (and therefore cost) of necessary infrastructure in order to support development, assuming that almost the same number of houses is built in a smaller area. Pejchar et al. (2007) notice that the National Association of Home Builders calculated that a medium developmental complex in a protected area costs $34 \%$ less in order to be developed compared to a conventional area (citing Thomas, 1991). They also add that there are plenty of proofs indicating that vicinity to open space, like protected areas, increase the value of a property whereas the bigger increases in values concern houses located in a area of approximately $455 \mathrm{~m}$ from permanent protected natural areas. Therefore, development based on the conservation of natural environment could potentially give competitive advantage to those who would choose it given that it would offer them the opportunity to differentiate their houses in relation to those which are part of the "classic developmental paradigm" which tends to offer limited variations in a rather common subject (Pejchar et al., 2007). However, as Pejchar et al. (2007) argue, it is estimated that development based on conservation entails a degree of risk and under specific circumstances could be considered as less advantageous because for instance, "the identification and protection of important ecological assets could eliminate the best potential home sites on a property [sic]".

A major characteristic of this discourse is the way that different and conflicting arguments coexisted in the same sentence reflecting a tendency to resolve real conflicts around development and conservation in theory. Although each discourse was not expressed in a concise way, as explained earlier in this chapter, it was especially in this approach that policies and goals not sufficiently combined in current practices were presented as totally compatible.

\subsection{Biodiversity conservation and sustainable development as complementary discourses: "Human-in-nature" approaches}

This discourse proved to be dominant among scientists, NGOs representatives and state employees. Nevertheless we must emphasize that this idea has been more directly 
expressed through individual arguments and has not, at least for most interviewees, been presented as a clear and concrete standpoint reflected in all individual questions. An important feature of this view is that is was expressed through calls for redefining or reconceptualizing both sustainable development and biodiversity conservation. Again, we could place these discourses in a continuum from approaches that argued for redefining both concepts through criticizing current practices, to more holistic approaches that were based on specific proposals towards adopting a new more integrative approach.

At the core of this discourse lies the understanding of society and environment as coevolving social-ecological systems. Interviewees argued that sustainable development should be interpreted as the type of development that encompasses both biodiversity conservation and human welfare, primarily defined as explicit support for environmental friendly activities, resilient local livelihoods and increased quality of life for the majority of local people. Therefore, current developmental trends were considered as non-compatible with conservation. Interviewees emphasized that those who support the need for conservation of biodiversity and sustainable development should become more critical against the wider-scale policies that threaten it and the specific actors who promote and actually profit from these (see also McAfee, 1999). They should also consider more carefully the connections between individual acts and the wider structures and processes that drive social and environmental practices and changes (see also Adams \& Hutton, 2007). It was argued that for the latter it is crucial to acknowledge the differentiation within local community groups as well as the variety of activities through which they interact with natural environment. Clearly taking into account the role of power and productive relations and the way that these influence human metabolism with nature was considered as crucial towards the above acknowledgement as well as towards resolving scale mismatches between natural and social systems. As a state employee explained:

"In natural resource conflicts all social groups are not sharing equally either the costs or the benefits of conservation policy. This has been obvious in both cases, I mean in both Schinias and Zakynthos, and it was further aggravated by the fact that many people in these areas were obliged to make sacrifices whereas at the same time others remained unaffected from regulations despite the environmental disastrous character of their activities. [...] And moreover there is no official policy or strategy trying to explain and deal with the reasons behind non-sustainable activities of local people. Maybe because in this case state would have to blame itself and then who could ever be convinced for biodiversity conservation from a state which is mainly responsible for its loss?"

In this view sustainable development is closely related to social equity and local community livelihoods and therefore local perceptions regarding issues of social justice and improvement of life conditions are considered as crucial factors for the success of projects aiming at combining development and conservation. However, it was pinpointed that this approach in the Greek case is not an established trend and therefore besides reference to some specific cases where initiatives towards this direction have been adopted, this was mainly conceptualized as a proposal for future Greek policies and practices. As a scientist explained:

"The main goal of current practices of biodiversity conservation in Greece, along with the absence of references to a "societal economy" which could potentially distribute the benefits of the management agencies established in protected areas to local communities, are indicatory of the dominant direction 
of present initiatives towards the commercialization of the natural environment and the exclusion of local people from their areas. They are reproducing a dichotomy between society and nature arguing at the same time that this is the only realistic approach in the era of modernity. Future integrative policies will be successful only if they escape from such dipoles. After all, our experiences with areas such as Zakynthos or Schinias confirm this argument".

Interviewees adopting this view emphasized the role of multiple types of knowledge in the process of designing, implementing and evaluating conservation projects. The role of scientific knowledge and monitoring proved to be of fundamental importance for assessing whether sustainable development is actually combined with conservation, by analyzing the impacts of development projects for ecosystems. Similarly, traditional and lay knowledge were considered as necessary tools for assessing the incorporation of socio-economic and cultural objectives in conservation-development projects as well as for resolving mismatches occurring from inaccurate analysis of the interactions between ecosystem processes and human activities.

It is remarkable that some interviewees while analyzing their proposals for improving the situation in Schinias, they focused on the need to realize that in order to minimize the degradation of ecosystems in the region due to a set of interrelated factors (fragmentation and habitat loss, hydrologic regime, residential and tourist development, etc.) an interdisciplinary designation of conservation policy that would be based on the interaction and interrelationship of social, political, ecological, economic and cultural conditions should be considered as a prerequisite. While assessing the situation in Schinias National Park interviewees explained that it would be critical to promote sustainable development by integrating the social dimension in biodiversity conservation to improve the living standards of local community with investments in areas such as infrastructure for local people (sewers, flood control, biological control of mosquitoes, etc.), works to strengthen the family income, agrienvironmental schemes, economic incentives for environmental protection and compensation for loss of income. These actions could significantly restore the chronic unequal distribution of costs and benefits that state policies have promoted. In this view, sustainable development was perceived as a strategy which could potentially lead to resilient social-ecological systems. Similar insights were documented for the National Marine Park of Zakynthos.

Similarly, the principle of "participation" has been dominant in discussions whereas the role of local communities has been described as crucial during the designation and implementation of environmental policy with the main goal to promote sustainable development. Elements of the neo-populist paradigm can be traced here in stakeholders' discourses, mainly in the quotes of NGOs representatives, especially regarding the role of protected areas (see also Brown, 2002). However, it is important to notice that the reference to ICDPs projects (for further details about ICDPs see Garnett et al., 2007), which has been a dominant strategy for combining development and conservation worldwide, was not considered as relevant for the Greek case, something also evident from the fact that this kind of projects are actually non-existent. The latter is also related to the fact that discourses about local communities leaving in harmony with nature tend to be popular in "developing" countries and not in "developed" ones.

Concurrently, some interviewees, mainly researchers, claimed that in order to make stakeholders networks to effectively work, research should be focused on the investigation 
of the socio-economic and political power relations within and among social groups (see also Paulson et al., 2003) across scales. The designation of a socially inclusive conservation strategy, including specific incentives, compensation measures and support for traditional human activities, at national level was considered as necessary in order to achieve real changes at both regional and local levels. Such initiatives can be based on the benefits from the establishment of linkages between humans and protected areas (Hoole \& Berkes, 2010) and on schemes that would deal with the unequal distribution of cost and benefits that conservation policies produce (Apostolopoulou \& Pantis, 2010).

Finally, interviewees argued that issues such as the definition of "local community" and the description of how societal participation in implementing conservation programs will occur in practice should no longer be located on the margins of the dominant approaches. It was argued that conflicts over natural resources cannot be treated as "technical" issues that need to be resolved by the appropriate "communication strategies".

The adoption of adaptive co-management strategies (see Armitage et al., 2009) was a dominant proposal in this discourse. The latter was perceived as a strategy which could lead to the improvement of the current situation through the transition to a comprehensive and long-term adaptive management plan where a variety of management measures will be implemented and tested in practice to achieve the integration of sustainable development and biodiversity conservation in a context of environmental justice. Similarly, a participatory and transparent decision-making process was considered by interviewees as necessary in order to implement integrative conservation and development strategies according to the social needs of the majority of local people.

\section{Conclusion}

It is evident that different discourses regarding sustainable development and biodiversity conservation have core differences on the way they interpret and frame the relationship between nature and human society. The conceptualizations of the role of local community, NGOs, the state and the market have fundamental consequences for the way that biodiversity conservation and sustainable development as well as potentials for their integration are being understood and defined. Undoubtedly, there is a huge confusion around all these terms evident in the apparent difficulty of the interviewees to explicitly explain their ideas and offer integrative approaches whereas in many cases same observations on several points were used to support very different arguments (see also Brechin et al., 2002). The fact that different agencies interpret the linkages between development and conservation in different ways, along with the different policy instruments implemented in protected areas, results in a range of prescriptions and management strategies (Brown, 2002). This confusion is directly related to the variety of cultural and ideological perspectives as well as to the influence of powerful economic interests and especially to the fact that "by no means all of these different interests and normative notions about biodiversity concern human welfare although they may be invoked in its name (Blaikie \& Jeanrenaud, 1997)". The existence of many contradictory tendencies and rivalries in development strategies requires a thorough analysis of the social construction of nature especially given that the discourses regarding conservation and sustainability are directly linked to the broader systems of development and power (Nygren, 1998). 
Towards this direction the role of the state, the market and local communities should be carefully analyzed. Apart from the overall role of NGOs, the "civil society" term is still unclear and problematic, since it encompasses the definition of society as a homogeneous entity. In the current reconstruction of the term, the "civil society" concept diminishes the structural conflicts that occur among different social groups (Meiksins Wood, 1998). The failure to recognize differences within local communities has been highly criticized by a broad variety of researchers (Agrawal \& Gibson, 1999; Brosius et al., 2005; Brosius et al., 1998). Similarly, focusing on "actors" rather than state and market structures and processes tends to remove agents from structures forgetting that the central questions related to environmental degradation and rural deprivation are to be found in land tenure relations, market dependencies, organization of economies, and violence against local knowledge (Bebbington, 1993; Nygren, 1998). The latter are primarily responsible for serious mismatches between social and ecological sustainability whereas they are strongly related to the fact that individuals in fundamental societal roles have the power to influence ecological patterns and processes at scales beyond expected. This is highly apparent in the case of biodiversity conservation and sustainable development with the example of Protected Areas, to be of the most typical ones. This, in turn, causes several misconceptions, mismatches and conflicts of interest among the various administrative levels as well as between and within institutional and governance structures and processes.

Today, it is considered that due to scientific advances and new political coalitions new approaches are emerging that align development with conservation linking human and environmental well being (Daily \& Matson, 2008). However, we could argue that combining nature protection with social justice has not yet been implemented as a general strategy whereas the role of sustainability remains complicated and quite ambiguous in current policies and practices (Apostolopoulou \& Pantis, 2010; Apostolopoulou, 2010; Brechin et al., 2002). Therefore, it is of fundamental importance to unravel current stakeholders' discourses in order to analyze current deficits in both theory and practice. The latter is, in turn, critical for the designation and implementation of future integrating policies which would consider biodiversity conservation and sustainable development as complementary goals in the context of a new positive relationship between nature and human society.

\section{Acknowledgements}

An important part of this study was funded by the EU European Social Fund (75\%) and the Greek Ministry of Development - GSRT (25\%). Funding for a part of this study was also provided by the Large-Scale Integrating Project within FP7 SCALES (grant 226 852). We thank the many people and organizations for providing us with information necessary for our research.

\section{References}

Abakerli, S. (2001). A critique of development and conservation policies in environmentally sensitive regions in Brazil. Geoforum, Vol.32, pp. 551-565 
Adams, W.M. \& Hulme, D. (2001). Conservation and communities: Changing narratives, policies and practices in African conservation, in: African Wildlife and Livelihoods: The Promise and Performance of Community Conservation, D. Hulme \& M. Murphree, (Eds), 9-23, James Currey, London

Adams, W.M. \& Hutton, J. (2007). People, Parks and Poverty: Political Ecology and Biodiversity Conservation. Conservation and Society, Vol.5, pp. 147-183

Adams, W.M., Aveling, R., Brockington, D., Dickson, B., Elliott, J., Hutton, J., Roe, D., Vira, B. \& Wolmer, W. (2004). Biodiversity conservation and the eradication of poverty. Science, Vol.306, pp. 1146-1149

Agrawal, A. \& Gibson, C.C. (1999). Enchantment and disenchantment: The role of community in natural resource conservation. World Development, Vol.27, pp. 629649

Apostolopoulou, E. \& Pantis, J.D. (2010). Development plans versus conservation: explanation of emergent conflicts and state political handling. Environment and Planning A, Vol. 42, pp. 982-1000

Apostolopoulou, E. \& Pantis, J.D. (2009). Conceptual gaps in the national strategy for the implementation of the European Natura 2000 conservation policy in Greece. Biological Conservation, Vol.142, pp. 221-237

Apostolopoulou, E. (2010). Critique of the dominant developmental ideology regarding the nature-society relationship: The case of conservation policies. Outopia, Vol.91, pp. 87-106 (in Greek)

Armitage, D.R., Plummer, R., Berkes, F., Arthur, R.I., Charles, A.T., Davidson-Hunt, I.J., Diduck, A.P., Doubleday, N.C., Johnson, D.S., Marschke, M., McConney, P., Pinkerton, E.W. \& Wollenberg, E.K. (2009). Adaptive co-management for socialecological complexity. Frontiers in Ecology and the Environment, Vol.7, pp. 95-102

Bebbington, A. (1993). Modernization from below: an alternative indigenous development? Economic Geography, Vol.69, pp. 274-292.

Berghoefer, U., Rozzi, R. \& Jax, K. (2010). Many eyes on nature: diverse perspectives in the Cape Horn Biosphere Reserve and their relevance for conservation. Ecology and Society, 15(1): 18, Available from http://www.ecologyandsociety.org/vol15/iss1/art18/

Bishop, K.D. \& Phillips, A.A.C. (1993). Seven Steps to Market - the Development of the Market-led Approach to Countryside Conservation and Recreation. Journal of Rural Studies, Vol.9, pp. 315-338

Blaikie, P. \& Jeanrenaud, S. (1997). Biodiversity and human welfare, In: Social change and conservation: environmental politics and impacts of national parks and protected areas, $\mathrm{K}$. Ghimire \& M.P. Pimbert, (Eds), 46-70, Earthscan, London

Blowers, A. (1998). Power, participation and partnership, In: Cooperative Environmental Governance: Public-Private Agreements as a Policy Strategy, P. Glasbergen, (Ed.), 229249, Kluwer Academic Publishers, Dordrecht

Brand, U. \& Görg, C. (2003). The state and the regulation of biodiversity. International biopolitics and the case of Mexico. Geoforum, Vol.34, pp. 221-233 
Brechin, S.R., Wilshusen, P.R., Fortwangler, C.L. \& West, P.C. (2002). Beyond the square wheel: toward a more comprehensive understanding of biodiversity conservation as social and political process. Society and Natural Resources, Vol.15, pp. 41-64

Brosius, J.P., Tsing, A.L. \& Zerner, C. (2005). Communities and Conservation: Histories and Politics of Community-Based Natural Resource Management, Altamira Press, Walnut Creek, USA

Brosius, J.P., Tsing, A.L. \& Zerner, C. (1998). Representing communities: histories and politics of community-based natural resource management. Society and Natural Resources, Vol.11, pp. 157-168.

Brown, K. (2002). Innovations for conservation and development. The Geographical Journal, Vol.168, pp. 6-17

Brown, K. (1998). The political ecology of biodiversity, conservation and development in Nepal's Terai: confused meanings, means and ends. Ecological Economics, Vol.24, pp. 73-88

Cernea, M.M. \& Schmidt-Soltau, K. (2006). Poverty risks and national parks: Policy issues in conservation and resettlement. World Development, Vol.34, pp. 1808-1830

Cernea, M.M. (1997). The risks and reconstruction model for resettling displaced populations. World Development, Vol.25, pp. 1569-1589

Chapin, M. (2004). A challenge to conservationists. World Watch Magazine, Vol.11-12, pp. 1731

Chatty, D. \& Colchester, M. (2002). Conservation and Mobile Indigenous Peoples: Displacement, Forced Resettlement and Sustainable Development, Berghahn Press, New York

Clark, B. \& York, R. (2005). Dialectical Materialism and Nature: An Alternative to Economism and Deep Ecology. Organization and Environment, Vol.18, pp. 318-337

Corbin, J. \& Strauss, A. (1990). Grounded theory research: procedures, canons, and evaluative criteria. Qualitative Sociology, Vol.13, pp. 3-21

Cumming, G.S., Cumming, D.H.M. \& Redman, C.L. (2006). Scale Mismatches in SocialEcological Systems: Causes, Consequences, and Solutions. Ecology and Society 11(1): 14, Available from

http://www.ecologyandsociety.org/vol11/iss1/art14/

Daily, G.C. \& Matson, P.A. (2008). Ecosystem services: from theory to implementation. PNAS, Vol.105, pp. 9455-9456

Davidson-Hunt, I.J. \& Berkes, F. (2003). Nature and society through the lens of resilience: toward a human-in-ecosystem perspective, In: Navigating Social-Ecological Systems, F. Berkes, J. Colding \& C. Folke, (Eds.), 53-82, Cambridge University Press

De Angelis, M. (2003). Neoliberal Governance, Reproduction and Accumulation. The Commoner, Spring/Summer 2003, Available from http://www.thecommoner.org

Dryzek, J.S. (1997). The Politics of the Earth: Environmental Discourses, Oxford University Press, Oxford

Fisher, D.R. \& Freudenburg, W.R. (2001). Ecological modernization and its critics: assessing the past and looking toward the future. Society and Natural Resources, Vol.14, pp. 701-709

Foster, J.B. (2002). Ecology against capitalism, Monthly Review Press, New York 
Fraser, N. (1996). Clintonism,Welfare, and the Antisocial Wage: The Emergence of a Neoliberal Political Imaginary, In: Marxism in the Postmodern Age: Confronting the New World Order, A. Callari, S. Cullenberg, C., Biewener, (Eds), 493-505, The Guildford Press, New York and London

Garnett, S.T., J. Sayer \& Du Toit, J. (2007). Improving the effectiveness of interventions to balance conservation and development: a conceptual framework. Ecology and Society 12(1): 2, Available from http://www.ecologyandsociety.org/vol12/iss1/art2/

Geoghegan, T. \& Renard, Y. (2002). Beyond community involvement: lessons from the insular Caribbean. Parks, Vol.12, pp. 16-25

Gjertsen, H. (2005). Can habitat protection lead to improvements in human well-being? Evidence from marine protected areas in the Philippines. World Development, Vol.33, pp. 199-217

Haggerty, J.H. (2007). I'm not a greenie but ...: environmentality, eco-populism and governance in New Zealand: experiences from the Southland whitebait fishery. Journal of Rural Studies, Vol.23, pp. 222-237

Hajer, M.A. (1996). Ecological modernization as cultural politics, In: Risk, Environment and modernity: towards a new ecology, S. Lash, B. Szerszynski, B. Wynne, B., (Eds), 246268, Sage publications, London

Hajer, M.A. (1995). The politics of environmental discourse: Ecological modernization and the policy process, Oxford University Press, Oxford

Hanley, N. \& Shogren, J.F. (2002). Awkward choices: economics and nature conservation, In: Economics, Ethics and Environmental Policy: Contested Choices, D.W. Bromley \& J. Paavola, (Eds), Blackwell Publishing, Oxford

Harper, J. (2002). Endangered species, Carolina Academic Press, Durham, North Carolina

Hoole, A. \& Berkes, F. (2010). Breaking down fences: Recoupling social-ecological systems for biodiversity conservation in Namibia. Geoforum, Vol.41, pp. 304-317

Igoe, J. (2006). Measuring the costs and benefits of conservation to local communities. Journal of Ecological Anthropology, Vol.10, pp. 72-77

Jamal, T., Everett, J. \& Dann, G.M.S. (2003). Ecological rationalization and performative resistance in natural area destinations. Tourist studies, Vol.3, pp. 143-169

Jänicke, M. (1997). The political system's capacity for environmental policy, In: National Environmental Policies: A Comparative Study of Capacity-Building, M. Jänicke \& H. Weidner, (Eds), 1-24, Springer Verlag, Berlin

Jenkins, W.A., Murray, B.C., Kramer, R.A. \& Faulkner, S.P. (2010). Valuing ecosystem services from wetlands restoration in the Mississippi Alluvial Valley. Ecological Economics, Vol.69, pp. 1051-1061

Jim, C.Y. \& Chen, W.Y. (2009). Ecosystem services and valuation of urban forests in China. Cities, Vol.26, pp. 187-194

Kalamandeen, M. \& Gillson, L. (2007). Demything “wilderness": implications for protected area designation and management. Biodiversity and Conservation, Vol.16, pp. 165-182

Kiss, A. (2004). Is community-based ecotourism a good use of biodiversity conservation funds? Trends in Ecology and Evolution, Vol.19, pp. 232-237 
Kittinger, J.N., Dowling, A., Purves, A.R., Milne, N.A. \& Olsoon, P. (2011). Marine Protected Areas, Multiple-Agency Management, and Monumental Surprise in the Northwestern Hawaiian Islands. Journal of Marine Biology doi:10.1155/2011/241374

Knudsen, A. (1999). Conservation and controversy in Karakoram: Khunjerab National Park, Pakistan. Journal of Political Ecology, Vol.6, pp. 1-30

Lange, G.-M. \& Jiddawi, M. (2009). Economic value of marine ecosystem services in Zanzibar: Implications for marine conservation and sustainable development. Ocean \& Coastal Management, Vol.52, pp. 521-532

MA (Millenium Ecosystem Assessment) (2003). Ecosystems and human well-being, Island Press, Washington

McAfee, K. (1999). Selling nature to save it? Biodiversity and green developmentalism. Environment and Planning D: Society and Space, Vol.17, pp. 133-154

McCarthy, J. (2006). Neoliberalism and the Politics of Alternatives: Community Forestry in British Columbia and the United States. Annals of the Association of American Geographers, Vol.96, pp. 84-104

McCauley, D.J. (2006) Selling out on nature. Nature, Vol.443, pp. 27-28

McNeeley, J.A. (1993). Economic incentives for conserving biodiversity: Lessons for Africa. Ambio, Vol.22, pp. 144-150.

Meiksins Wood, A., 1998. The communist manifesto 150 years later. Monthly Review Press, New York.

Mol, A.P.J. \& Sonnenfield, D.A. (2000). Ecological modernization around the world: Perspectives and critical debates, Frank Cass, London

Mol, A.P.J. \& Spaargaren, G. (2000). Ecological Modernization Theory in Debate: A Review. Environmental Politics, Vol.9, pp. 17-49

Mol, A.P.J. (2002). Ecological modernization and the global economy. Global Environmental Politics, Vol.2, pp. 92-115

Mol, A.P.J. (1995). The Refinement of Production: Ecological Modernization Theory and the Chemical Industry, Van Arkel, Utrecht, The Netherlands

Mukhopadhyay, A. (2005). Merchandising nature. Political ecology of biodiversity, Working paper series, Indian Institute of Management, Calcutta

Naxakis, C. (1997). The environmental impacts of the Maastricht Treaty. Outopia, Vol. 26, pp. 107-118 (in Greek)

Nygren, A. (2005). Community-based forest management within the context of institutional decentralization in Honduras. World Development, Vol.33, pp. 639-655

Nygren, A. (1998). Environment as Discourse: Searching for Sustainable Development in Costa Rica. Environmental Values, Vol.7, pp. 201-222

Padgett, D.K. (1998). Qualitative methods in social work research: Challenges and rewards, Sage, Thousand Oaks, CA

Patton, M.Q. (2002). Qualitative research and evaluation methods, Sage, Thousand Oaks, CA. 3rd edition

Paulson, S., Gezon, L.L. \& Watts, M. (2003). Locating the political in political ecology: an introduction. Human Organization, Vol. 62, pp. 205-217 
Pejchar, L., Morgan, P.M., Caldwell, M.R., Palmer, C. \& Daily, G.C. (2007). Evaluating the Potential for Conservation Development: Biophysical, Economic, and Institutional Perspectives. Conservation Biology, Vol.21, pp. 69-78

Peterson, M.N., Peterson, M.J. \& Peterson T.R. (2005). Conservation and the myth of consensus. Conservation Biology, Vol.19, pp. 762-767

Phillips, L. \& Jørgensen, W. (2006). Discourse Analysis as Theory and Method, Sage Publications, London

Randall, A. (2002). Benefit cost considerations should be decisive when there is nothing more important at stake, In: Economics, Ethics and Environmental Policy: Contested Choices, D.W. Bromley \& J. Paavola, (Eds.), Blackwell Publishing, Oxford

Redford, K.H. \& Adams, W.M. (2009). Payment for ecosystem services and the challenge of saving nature. Conservation Biology, Vol.23, pp. 785-787

Salafsky, N. \& Wollenberg, E. (2000). Linking livelihoods and conservation: a conceptual framework and scale for assessing the integration of human needs and biodiversity. World Development, Vol.28, pp. 1421-1438

Scholte, J.A. (2004). Civil society and democratically accountable global governance. Government and Opposition, Vol.39, pp. 211-233

Searle, M. (2000). Phantom Parks: The Struggle to Save Canada's National Parks, Key Porter Books, Toronto

Sodhi, N.S., Lee, T.M., Sekercioglu, C.H., Webb, E.L., Prawiradilaga, D.M., Lohman, D.J., Pierce, N.E., Diesmos, A.C., Rao, M. \& Ehrlich, P.R. (2010). Local people value environmental services provided by forested parks. Biodiversity and Conservation, Vol.19, pp. 1175-1188

Spaargaren, G. (2000). Ecological modernization theory and domestic consumption. Journal of Environmental Policy \& Planning, Vol.1, pp. 323-335

Spaargaren, G. (1997). The ecological modernization of production and consumption: essays in environmental sociology, Wageningen Agricultural University, PhD thesis.

Strauss, A. \& Corbin, J. (1998). Basics of Qualitative Research, Techniques and Procedures for Developing Grounded Theory, Sage Publications, London

Swetnam, R.D., Fisher, B., Mbilinyi, B.P., Munishi, P.K.T., Willcock, S., Ricketts, T., Mwakalila, S., Balmford, A., Burgess, N.D., Marshall, A.R. \& Lewis, S.L. (2011). Mapping socio-economic scenarios of land cover change: A GIS method to enable ecosystem service modeling. Journal of Environmental Management, Vol.92, pp. 563574

Tallis, H., Kareiva, P., Marvier, M. \& Chang, A. (2008). An ecosystem services framework to support both practical conservation and economic development. PNAS, Vol.105, pp. 9457-9464

Thiele, L.P. (1999). Environmentalism for a new millennium: the challenge of coevolution, Oxford University Press, Oxford

Vira, B. \& Adams, W.M. (2009). Ecosystem services and conservation strategy: beware the silver bullet. Conservation Letters, Vol.2, pp. 158-162

Vlachou, A. (2005). Debating sustainable development. Rethinking Marxism, Vol.17, pp. 627638 
WCED (World Commission on Environment and Development) (1987). Our Common Future, Oxford University Press, Oxford

Weale, A. (1992). The new politics of pollution, Manchester University Press, Manchester

York, R. \& Rosa, E.A. (2003). Key Challenges to Ecological Modernization Theory: Institutional Efficacy, Case Study Evidence, Units of Analysis, and the Pace of EcoEfficiency. Organization E Environment, Vol.16, pp. 273-288 


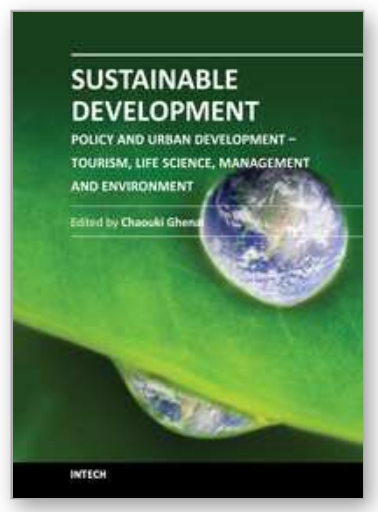

\author{
Sustainable Development - Policy and Urban Development - \\ Tourism, Life Science, Management and Environment \\ Edited by Prof. Chaouki Ghenai
}

ISBN 978-953-51-0100-0

Hard cover, 478 pages

Publisher InTech

Published online 24, February, 2012

Published in print edition February, 2012

The technological advancement of our civilization has created a consumer society expanding faster than the planet's resources allow, with our resource and energy needs rising exponentially in the past century. Securing the future of the human race will require an improved understanding of the environment as well as of technological solutions, mindsets and behaviors in line with modes of development that the ecosphere of our planet can support. Sustainable development offers an approach that would be practical to fuse with the managerial strategies and assessment tools for policy and decision makers at the regional planning level.

\title{
How to reference
}

In order to correctly reference this scholarly work, feel free to copy and paste the following:

Evangelia Apostolopoulou, Evangelia G. Drakou, and John D. Pantis (2012). Unraveling Stakeholders' Discourses Regarding Sustainable Development and Biodiversity Conservation in Greece, Sustainable Development - Policy and Urban Development - Tourism, Life Science, Management and Environment, Prof. Chaouki Ghenai (Ed.), ISBN: 978-953-51-0100-0, InTech, Available from:

http://www.intechopen.com/books/sustainable-development-policy-and-urban-development-tourism-lifescience-management-and-environment/unraveling-stakeholders-discourses-regarding-sustainabledevelopment-and-biodiversity-conservation-i

\section{INTECH}

open science | open minds

\author{
InTech Europe \\ University Campus STeP Ri \\ Slavka Krautzeka 83/A \\ 51000 Rijeka, Croatia \\ Phone: +385 (51) 770447 \\ Fax: +385 (51) 686166 \\ www.intechopen.com
}

\author{
InTech China \\ Unit 405, Office Block, Hotel Equatorial Shanghai \\ No.65, Yan An Road (West), Shanghai, 200040, China \\ 中国上海市延安西路65号上海国际贵都大饭店办公楼 405 单元 \\ Phone: +86-21-62489820 \\ Fax: +86-21-62489821
}


(C) 2012 The Author(s). Licensee IntechOpen. This is an open access article distributed under the terms of the Creative Commons Attribution 3.0 License, which permits unrestricted use, distribution, and reproduction in any medium, provided the original work is properly cited. 